\title{
PENGARUH BUDAYA KERJA TERHADAP KINERJA PEGAWAI DI KANTOR KEMENTERIAN AGAMA KABUPATEN GUNUNG MAS PROVINSI KALIMANTAN TENGAH
}

\section{The influence of working cultures on employee performance in the Ministry of Religious Affairs in Gunung Mas District, Central Kalimantan Province}

\section{Mambang* \\ Harmini \\ Universitas Muhammadiyah Palangkaraya, Palangka Raya, \\ Central Kalimantan, Indonesia \\ email: \\ mambang@umpalangkaraya.ac.id}

\begin{abstract}
Abstrak
Penelitian ini bertujuan untuk mengetahui pengaruh budaya kerja terhadap kinerja pegawai di Kantor Kementrian Agama Kabupaten Gunung Mas Kalimantan Tengah, dengan mengajukan hipotesus sebagai berikut: "Terdapat pengaruh yang nyata positif atau pengaruh budaya kerja terhadap kinerja pegawai”. Metode yang digunakan dalam penelitian ini adalah kuantitatif. Sampel dalam penelitian ini berjumlah 45 orang, dengan menggunakan teknik total sampling. Teknis pengumpulan data menggunakan kuesioner (angket) yang dibagikan kepada masingmasing pegawai Kantor Kementrian Agama Kabupaten Gunung Mas. Teknik analisa data dalam penelitian ini menggunakan metode Regrei Linier Sederhana.
\end{abstract}

\begin{abstract}
This research aims to determine the influence of work culture on the performance of employees in the Office of the Ministry of Religious Affairs of Gunung Mas Regency of Central Kalimantan, by applying hypothesis as follows: "There is a real positive influence or influence Working culture to employees ' performance. " The method used in this study is quantitative. The samples in this study amounted to 45 people, using a total sampling technique. Technical data collection using questionnaires that are distributed to the employees of the Ministry of Religious Affairs at Gunung Mas District office. The data analysis technique in this study uses the simple linear Regret method.
\end{abstract}

\section{Accepted}

January 2015

Published

April 2015

\section{PENDAHULUAN}

"Budaya kerja dalam suatu organisasi diartikan sebagai nilai sistem yang diyakini, dipelajari, dan diterapkan oleh semua anggota organisasi serta dikembangkan secara berkesinambungan" (Pengembangan Budaya Kerja Depertemen Agama, 2009:3). Budaya kerja dapat berfungsi sebagai perekat dan dapat dijadikan acuan berperilaku bagi anggota organisasi untuk mencapai tujuan yang ditetapkan.

Budaya kerja dapat dikenali wujudnya dari nilai-nilai yang terkandung didal sikap dan perilaku seseorang, kelompok, organisasi sistem kerja ketika pegawai melaksanakan tugas.
Melaksanakan budaya kerja mempunyai arti yang sangat dalam, karena akan merubah sikap dan perilaku suumber daya manusia unruk mencapai produktivitas kerja yang lebih tinggi dalam menghadapi tantangan masa depan.

Kinerja merupakan tanggung jawab setiap individu terhadap pekerjaannya. Guna mewujudkan tata pemerintahan yang baik, prioritas pembangunan bidang penyelenggaraan negara diarahkan pada upaya peningkatan kinerja birokrasi, yaitu menciptakan kondisi yang kondusif bagi terpenuhinya kebutuhan masyarakat, meningkatkan kualitas pelayanan kepada masyarakat, dan menekan tingkat penyalahgunaan kewenangan oleh sumber daya manusia apartur. 
Kantor Kementrian Agama Kabupaten Gunung Mas sebagai satuan kerja merupakan satu organisasi yang dinamis dan berorientasi pada kinerja. Dalam perkembangnnya saat ini yang sering muncul menjadi permasalahan tindak indisipliner masih di seputar halhal kalsik, diantaranya ialah masih banyak ditemukan pegawai yang terlambat masuk kerja dan pulang kerja lebih cepat dari waktu yang telah ditentukan. Selain itu masih banyak ditemukan ketidak hadiran pegawai pada hari kerja dan jam kerja, meskipun jika dilihat dari daftar hadir harian selalu penuh.

Selanjutnya sebagian pegawai merangkap dalam mengerjakan tugas dan fungsinya, hal ini dapat dilihat dari uraian tugas pegawai bersangkutan, dimana seharusnya untuk menghasilkan kinerja berkualitas idealnya tugas dan fungsi tersebut dikerjakan oleh beberapa orang pegawai, sementara di sisi lain sebagian pegawai uraian tugasnya sangat sedikit sehingga banyak memliki waktu luang yang pda akhirnya pegawai tersebut terlihat melakukan aktifitas lain di luar tufoksinya. Jika hal ini terus dibiarkan dikhawatirkan akan berimbas terhadap menurunnya kualitas kinerja pegawai khususnya dan kinerja kantor pada umumnya.

\section{Budaya Kerja}

"Budaya kerja adalah suatu falsafah yang didasari oleh pandangan hidup sebagai nilai-nilai yang menjadi sifat, kebiasaan dan kekuatan pendorong, membudaya dalam kehidupan suatu kelompk masyarakat atau organisasi, kemudian tercermin dari sikap menkalani perilaku, kepercayaan, cita-cita, pendapat dan tindakan yang terwujud sebagai "kerja” atau "bekerja” (Gering Supriyadi dan Tri Guno, 2003:8)

Menurut Peraturan Menteri Pendayagunaan Apartur Negara dan Reformasi Birokrasi Republik Indonesia (PERMENPAN) Nomor 39 (2012:4), budaya kerja diartikan sebagai "sikap dan perilaku individu dan kelompok yang didasari atas nilai-nilai yang diyakini kebenarannya dan telah menjadi sifat serta kebiasaan dalam melaksanakan tugas dan pekerjaan sehari-hari”.
Pencapaian peningkatan kualitas yang lebih baik tersebut, diharapkan bersumber dari setiap individuindividu yang terkait dalam organisasi kerja itu sendiri. Ketika individu-individu ini masuk kedalam sebuah instansi, maka akan terjadi penyesuaian nilai-nilai, norma-norma, sikap dan perilaku yang diinginkan oleh instansi demi mencapai cita-cita atau tujuannya. Perubahan tersebut memakan waktu, komitmen, kedisiplinan dan upaya yang luar biasa.

Instansi yang memiliki budaya kerja yang kuat akan dapat memperoleh hasil yang lebih baik. Hal ini dikarenakan para pegawainya telah mengetahui dan memahami "pekerjaan apa yang harus dilakukan dan bagaimana cara menyelesaikan pekerjaan tersebut".

Secara sederhana, buday kerja berarti cara pandang atau cara seseorang memberikan makna terhadap kerja. Dengan demikian budaya kerja apartur negara dapat difahami sebagai cara pandang serta suasana hati yang menumbuhkan keyakinan yang kuat atas dasar nilai-nilai yang diyakininya, serta memiliki semangat yang tinggi dan bersungguh-sungguh untuk mewujudkan prestasi kerja terbaik.

\section{Indikator Budaya Kerja}

Berdasarkan Peraturan Menteri Pendayagunaan Apartur Negara dan Reformasi Birokrasi Republik Indonesia (PERMENPAN) Nomor 39 (2012:5) indikator budaya kerja adalah:
a. Pemahaman terhadap makna bekerja
b. Sikap terhadap pekerjaan atau apa yang dikerjakan
c. Sikap terhadap lingkungan pekerjaan
d. Sikap terhadap waktu
e. Sikap terhadap alat yang digunakan untuk bekerja
f. Etos kerja
g. Perilaku ketika bekerja atau mengambil keputusan

\begin{abstract}
Kinerja
Konsep kinerja pada dasarnya merupakan perubahan atas pergeseran paradigma dari konsep produktivitas. Pada awalnya, orang sering kali menggunakan istilah produktivitas untuk menyatakan
\end{abstract}


kemampuan seseorang atau organisasi dalam mencapai tujuan atas sasaran tertentu. Menurut Anderson (Sudarmanto,2009:7) "Paradigma produktivitas yang baru adalah paradigma kinerja secara aktual yang menuntut pengukuran secara aktual keseluruhan kinerja organisasi, tidak hanya efisiensi atau dimensi fisik, tetapi juga dimensi non fisik (intangible).

Pengertian kinerja dapat dikategorikan ke dalam dua garis besar pengerian, yaitu:

I. Kinerja merujuk pengertian sebagai hasil. Dalam konteks hasil ada beberapa pendapat yaitu:

- Menurut Bernadin (dalam Sudarmanto, 2009:8) kinerja merupakan "catatan hasil yang diproduksi atas fungsi pekerjaaj tertentu atau aktivitasaktivitas selama periode waktu tertentu". Bernadin menekankan pengertian kinerja sebagai hasil, bukan karakter sifat (trait) dan perilaku.

- Menurut Richard (dalam Sudarmanto, 2009:8) "Pengertian kinerja sebagai hasil juga terkait dengan produktivitas dan efektivitas.

2. Kinerja merujuk pengertian sebgai perilaku. Terkait dengan kinerja sebagai perilaku ada beberapa pendapat, yaitu:

- Menurut Murphy (dalam Sudarmanto, 2009:8) menyatakan bahwa "kinerja itu merupakan seperangkat perilaku yang relevan dengantujuan organisasi atau unit organisasi tempat orang bekerja".

- Menurut Cambell (dalam Sudarmanto, 2009:9) "Kinerja bukan konsekuensi atau hasil tindakan, tetapi tindakan itu sendiri”.

Whitemore ( dalam Hamzah B. Uno dan Nina Lamatenggo, 2012:59) mengemukakan "kinerja adalah pelaksanaan fungsi-fungsi yang dituntut dari seseorang". Pengertian ini merupakan pengertian yang menuntut kebutuhan paling minim untuk berhasil.

Pandangan lain dikemukakan King (dalam Hamzah B. Uno dan Nina Lamatenggo, 2012:6I) yang menjelaskan kinerja adalah "Aktivitas seseorang dalam melaksanakan tugas pokok yang dibebankan kepadanya”. Mengacu pada pandangan ini, dapat diinterpretasikan bahwa kinerja seseorang dihubungkan dengan tugas-tugas rutin yang dikerjakannya.

\section{Indikator Kinerja}

John Miner (Sudarmanto, 2009:I I), mengemukakan empat dimensi yang dapat dijadikan sebagai tolak ukur dalam menilai kinerja, yaitu: (I) Kualitas, (2) Kuantitas, (3) Penggunaan waktu kerja, (4) Kerjasama dengan orang lain dalam bekerja.

Bernadin (dalam Sudarmanto, 2009:12) menyampaikan ada enam kriteria dasar atau dimensi untuk mengukur kinerja, yaitu:

a. Quality terkait dengan proses atau hasil mendekati sempurna/ideal dalam memenuhi maksud atau tujuan

b. Quantity terkait dengan satuan jumlah atau kuantitas yang dihasilkan

c. Timeliness terkait dengan waktu yang diperlukan untuk menyelesaikan aktivitas atau menghasilkan produk

d. Cost-effectiveness terkait dengan tingkat penggunaan sumber-sumber organisasi (orang, uang, material, teknologi) dalam mendapatkan atau memperoleh hasil atau pengurangan pemborosan dalam penggunaan sumber-sumber organisasi.

e. Need for supervision terkait dengan kemampuan individu dapat menyelesaikan pekerjaan atau fungsifungsi pekerjaan tanpa asistensi pimpinan atau intervensi pengawasan pimpinan.

f. Interpersonal impact terkait dengan kemampuan individu dalam meningkatkan perasaan harga diri, keinginan baik, dan kerjasama diantara sesama pekerja dan anak buah.

\section{METODOLOGI}

Penelitian ini menggunakan metode penelitian kuantitatif. Data-data yang dikumpulkan berupa rangkaian atau kumpulan angka-angka. Penelitian ini dilakukan selama 3 bulan, mulai bulan Nopember 2013 sampai dengan Januari 20I4. Lokasi penelitian 
dilakukan di Kantor Kementrian Agama Kabupaten Gunung Mas, yang beralamat di Jalan Brigjen Katamso No. 60, Kuala Kurun. Teknik pengambilan sampel adalah dengan menggunakan sampel total, yang mana sampel dimbil dari semua populasi yaitu seluruh pegawai Kantor Kementrian Agama Kabupaten Gunung Mas yang berjumlah 45 orang.

\section{HASIL DAN PEMBAHASAN}

Berdasarkan pengujian hipotesis yang telah dilakukan dengan persamaan regresi linier sederhana membuktikan bahwa budaya kerja berpengaruh terhadap kinerja pegawai di Kantor Kementrian Agama Kabupaten Gunung Mas Provinsi Kalimantan Tengah. Hasil tersebut membuktikan, semakin tinggi budaya kerja maka kinerja pegawai juga akan tinggi, begitu pula sebaliknya, semakin rendah budaya kerja maka semakin rendah pula kinerja pegawai.

Untuk dapat menghasilkan kinerja yang baik, pegawai Kantor Kementrian Agama Kabupaten Gunung Mas harus mengetahui dan memahami dengan bagik tugas dan fungsinya sehinga pegawai yang bersangkutan mengetahui apa yang harus dilakukannya untuk memenuhi tuntutan tugas dan fungsinya sebagai pegawai.

Dari hasil penyebaran angket, diketahui bahwa pegawai Kantor Kementrian Agama Kabupaten Gunung Mas sudah mengetahui dengan baik tugas dan fungsinya masing-masing sehingga tugas tersebut dapat dikerjakan dan tidak perlu ada tugas yang dialihkan pada pegawai lainnya, hal ini dilihat dari $60 \%$ pegawai yang menjawab tidak setuju jika karena ketidak mampuannya menjalankan tugas, tugasnya dialihkan kepada pegawai lain. Dan 15,56\% menjawab sangat tidak setuju.

Untuk dapat menjalankan tugas dengan baik, diperlukan pedoman atau acuan untuk melaksanakan tugas pekerjaan sesuai dengan fungsi dan alat penilaian kinerja instansi pemerintah berdasarkan indikator- indikator teknis, administratif dan prosedural sesuai dengan tata kerja, prosedur kerja dan sistem kerja disebut Standar Operasional Prosedur (SOP), 42,22\% responden menjawab tidak setuju dan 4,44\% menjawab sangat tidak setuju bahwa Kantor Kementrian Agama Kabupaten Gunung Mas sudah memiliki SOP.

Penempatan pegawai sesuai dengan kemampuannya dalam bekerja juga perlu diperhatikan karena engan menempatkan sumber daya manusia yang tepat, tidak saja menguntungkan bagi organisasi tapi juga bagi pegawai yang bersangkutan. Sebanyak 46,67\% responden menhawab setuju dan 4,44\% menjawab sangat setuuju bahwa pegawai di Kantor Kementrian Agama Kabupaten Gunung Mas sudah ditempatkan sesuai dengan kemampuannya.

Pimpinan juga memiliki peranan yang sangat penting dalam keberhasilan pencapaian tujuan organisaai, berdasarkan jawaban responden pemimpin di Kantor Kementrian Agama Kabupaten Gunung Mas adalah tipe pemimpin yang mampu bekerja sama dengan bawahannya dalam upaya menyelesaikan tugas, hal ini terlihat dari $75,56 \%$ responden menjawabsetuju dan $13,33 \%$ menjawab sangat setuju.

Selain dapat bekerja sama dengan baik denga bawahannya, pimpinan di Kantor Kementrian Agama Kabupaten Gunung Mas juga bersedia memberi saran, koreksi, maupun kritik yang diperlukan bawahannya saat mengahadapi kendala dalam menjalankan tugasnya. Sebanyak 75,56\% persen responden menjawab tidak setuju dan 2,22\% menjawab sangat tidak setuju jika pimpinan di Kantor Kementrian Agama Kabupaten Gunung Mas adalah tipe pemimpin yang hanya menginginkan pekerjaan beres tanpa mau membero saran, koreksi, atau kritik.

Sebanyak 42,44\% responden setuju dan II, I I\% sangat setuju bahwa kinerja pegawai sering mendapat koreksi dari pimpinan, walaupun disisi lain ini menunjukan kelemahan pegawai dalam bekerja. $40 \%$ responden setuju dan $8,89 \%$ menyatakan sangat setuju bahwa ada 
pegawai yang sudah mengikuti sosialisasi dan workshop tapi belum maksimal dalam menjalankan tugasnya.

Penguasaan terhadap teknologi sangatlah penting diera digital yang semakin berkembang ini. 35,56\%responden mengaku setuju dan $22,22 \%$ sangat setuju bahwa pegawai di Kantor Kementrian Agama Kabupaten Gunung Mas sudah dapat mengikuti perkembangan teknologi.

Untuk meningkatkan kualitas diri pegawai, pimpina di Kantor Kementrian Agama Kabupaten Gunung Mas mempersilahkan bawahannya mengikuti kegiatan seperti sosialisasi, workshop dan lain-lain yang berkaitan dengan tugasnya. Kesempatan ini dipergunakan pegawai dengan baik. Pimpinan di Kantor Kementrian Agama Kabupaten Gunung mas selain mau memberi saran dan kritik pada bawahannya, juga bersedia menerima kritik dan saran dari bawahannya, begitu pula antar sesama pegawai. 84,44\% responden setuju dan $8,89 \%$ sangat setuju bahwa pemimpin dan pegawai lainnya bersedia menerima kritik dan saran dari orang lain.

Dalam hal i'tikad menyelesaikan pekerjaan, pegawai di Kantor Kementrian Agama Kabupaten Gunung Mas sudah baik karena memiliki inisiatif sendiri dalam upaya menyelesaikan pekerjaannya tanpa harus menunggu perintah dari pimpinan terlebih dahulu. Sebanyak $42,22 \%$ responden menjawab setuju dan $6,67 \%$ menyatakan sangat seuju bahwa pegwai di Kantor Kementrian Agama Kabupaten Gunung Mas sudah memiliki inisiatif untuk menyelesaikan pekerjaan tanpa diperintah pimpinan.

Tanggung jawab pegawai di Kantor Kementrian Agama Kabupaten Gunung Mas terhadap pekerjaannya juga sudah baik, hal ini dapat dilihat dari jawaban responden 46, $67 \%$ menyatakan tidak setuju dan $4,44 \%$ sangat tidak setuju bahwa ada pegawai yang tidak bertanggung jawab terhadap tugasnya. Juga 44,44\% responden menjawab tidak setuju dan $1 \mathrm{I}, \mathrm{I}$ I\% menjawab sangat tidak setuju ada pegawai yang meninggalkan tugasnya karena lebih mengutamakan urusan pribadi.

Dalam hal kedisiplinan, pegawai di Kantor Kementrian Agama Kabupaten Gunung Mas nampaknya belum disiplin. Hal ini terlihat dari $42,22 \%$ responden menjawab tidak setuju dan $4,44 \%$ sangat tidak setuju bahwa pegawai tepat waktu saat masuk kerja dan saat pulang kerja.

Ketidak disiplinan pegawai di Kantor Kementrian Agama Kabupaten Gunung Mas juga dapat tergambar dari jawaban responden yang menyatakan setuju $44,44 \%$ dan $20 \%$ menyatakan sangat setuju bahwa ada pegawai yang malas bekerja ditandai dengan jarang masuk kerja. Juga ada $31, \mathrm{I} / \%$ responden menjawab setuju dan $6,67 \%$ sangat setuju bahwa ada pegawai yang santai-santai saja dalam mengerjakan pekerjaannya. Jika hal ini terus berlanjut dapat dipastikan pegawai tidak dapat menyelesaikan pekerjaannya tepat waktu.

Dari hasil penelitian terhadap budaya kerja diharapkan cara pandang pegawai di Kantor Kementiran Agama Kabupaten Gunung Mas dalam memberi makna terhadap kerja semakin baik. karena budaya kerja berkaitan erat dangan perilaku dalam menyelesaikan pekerjaan. Organisasi yang memiliki budaya kerja yang kuat akan memperoleh hasil yang lebih baik. Hal ini dikarenakan para pegawainya telah mengetahui dan memahami "Pekerjaan apa yang harus dilakukan dan bagaimana cara menyelesaikan pekerjaan tersebut.

Dari uraian sebelumnya dapat dilihat bahwa budaya kerja berpengaruh terhadap kinerja peggawai, dimana perubahan budaya kerja dalam organisasi sangat memperngaruhi perubahan perilaku pegawai dalam organisasi tersebut.

\section{KESIMPULAN}

Berdasarkan hasil penelitian dan analisis data yang peneliti laksanakan di Kantor Kementrian Agama 
Kabupaten Gunung Maas dapat disimpulkan bahwa budaya kerja berpengaruh positif terhadap kinerja pegawai di Kantor Kementrian Agama Kabupaten Gunung Mas. Hasil analisa dengan menggunakan rumus analisis regresi linier didapatkan dengan persamaan regresi $y=22,87+0,41 x$ dengan kesimpulan:

I. Nilai konstanta (a) bernilai positif yaitu 22,87 artinya apabila variable budaya kerja dinyatakan nol maka variabel kinerja pegawai sebesar 22,87

2. Sedangkan koefisien variabel $x$ bidaya kerja (b) bernilai positif sebesar $0,41 x$ artinya apabila variabel budaya kerja meningkat sebesar I satuan, maka variabel y kinerja akan meningkat pula sebesar $0,41 x$.

Sehingga semakin tinggi budaya kerja maka kinerja pegawai juga akan tinggi, begitu juga sebaliknya, jika budaya kerja rendah maka kinerja pegawai akan rendah juga. Maka diharapkan kepada pihak Kantor Kementrian Agama Kabupaten Gunung Mas agar dapat membuat Standar Operasional Prosedur (SOP) sebagai acuan di dalam menjalankan aktifitas birokrasi lalu, Diharapkan pegawai Kantor Kementrian Agama Kabupaten Gunung Mas agar meningkatkan disiplin di dalam bekerja, selalu masuk kerja, masuk dan pulang kerja tepat waktu, sehingga pekerjaan dapat diselesaikan secara tuntas dan tepat waktu. Serta, pegawai Kantor Kementrian Agama Kabupaten Gunung Mas agar meningkatkan kualitas diri baik secara administrasi maupun dalam penguasaan teknologi.

\section{REFERENSI}

Ardana, I Komang, Ni Wayan Mujiati dan I Wayan Mudiartha Utama. 2012. Manajemen Sumber Daya Manusia. Yogyakarta: Graha IImu.

B. Uno, Hamzah dan Nina Lamatenggo. 20I2. Teori Kinerja dan Pengukurannya. Jakarta: Bumi Aksara.

El Widdah, Minah, Asep Suryana dan Kholid Musyaddad, 2012. Kepemimpinan Berbasis Nilai dan Pengembangan Mutu Madrasah. Bandung: Alfabeta.

Inspektorat Jendral Departemen Agama RI. 2009. Pengembangan Budaya Kerja Departemen Agama. Jakarta: Depag Republik Indonesia.

Nasehudin, Toto Syatori dan Nanang Gozali, 2012. Metode Penelitian Kuantitatif. Bandung: Pustaka Setia.

PERMENPAN No. 39, 2012. Pedoman Pengembangan Budaya Kerja. Jakarta: KEMENPAN.

Purwanto, Erwan Agus dan Dyah Ratih Sulistyastuti, 20I2. Implementasi Kebijakan Publik : Konsep dan Aplikasinya di Indonesia. Yogyakarta: Penerbit Gava Media.

Setiawan, Toni. 2012. Manajemen Sumber Daya Manusia. Jakarta: Platinum.

Sudarmanto, 2009. Kinerja dan Pengembangan Kompetensi SDM. Yogyakarta: Pustaka Pelajar.

Supriyadi, Gering dan Tri Guno, 2003. Budaya Kerja Organisasi Pemerintah. Jakarta: Lembaga Administrasi Negara Republik Indonesia. 